\title{
Development of Physics Learning Media based on Guided Inquiry Model to Improve Students' Concepts Mastery and Creativity
}

\author{
Susilawati ${ }^{12^{*}}$, Ahmad Hardjono ${ }^{1,2}$, Lalu Muliyadi1 ${ }^{1}$, Christine P. Abo ${ }^{3}$ \\ ${ }^{1}$ University of Mataram, Lombok, West Nusa Tenggara, Indonesia. \\ ${ }^{2}$ University of Mataram, Lombok, West Nusa Tenggara, Indonesia. \\ ${ }^{3}$ Sultan Kudarat State University, Philippines
}

DOI: $\underline{10.29303 / \text { jossed.v2i2.711 }}$

\section{Article Info}

Received: April 19th 2021

Revised : September 30th, 2021

Accepted: October $18^{\text {th }}, 2021$

\begin{abstract}
This study aims to develop learning media based on guided inquiry models to improve students' concepts mastery and creativity in physics learning in senior high schools. The learning media in question is a ripple tank to explain the characteristics of a mechanical wave. Development research with the 4D model (define, design, development, dissemination) was conducted in this study, where the learning media developed met the criteria of validity, practicality, and effectiveness in improving students' concepts mastery and creativity. Evaluation of the learning media validity is carried out through a validation mechanism where the media is validated by 3 validators (media experts), while evaluation of the practicality and effectiveness of learning media through its implementation in dass involves students in two schools in Mataram City - Indonesia. The results of the study show that the learning media with the guided inquiry model are valid, practical, and effective in improving students' concepts mastery and creativity in learning physics. The results of further studies are described in this article.
\end{abstract}

Keywords: Concept mastery; creativity; guided inquiry model; learning media.

Citation: Susilawati, S., Hardjono, A., Abo, C. P. ., \& Muliyadi, L. (2021). Development of Physics Learning Media based on Guided Inquiry Model to Improve Students' Concepts Mastery and Creativity. Journal of Science and Science Education, 2(2), 68-71. https://doi.org/10.29303/jossed.v2i2.711

\section{Introduction}

Studying physics emphasizes a meaningful learning process that can develop the ability to understand nature scientifically (Susilawati et al, 2015) not only limited to memorizing activities but understanding (Kartini et al, 2020). Meaningful learning can take place in the laboratory, which allows students to manipulate materials in the surrounding environment to build knowled ge based on phenomena and the relationship between science concepts (Doyan et al, 2020). The laboratory is one of the means to bring students to understand real subject matter which provides a meaningful learning experience directly (Khasanah et al, 2020). The learning process contains

Email: susilawatihambali@unram.ac.id (*Corresponding Author) elements that are important to pay attention to, namely the learning model and learning media. These two elements are interrelated, where the use of certain learning models has an influence on the type of learning media used (Doyan et al, 2015).

The lack of research in the field of physics on mechanical wave matter at the senior high school level causes students to experience difficulty in understanding the basic concepts of mechanical waves (Lazonder et al, 2016; Jannah et al, 2016). The material of mechanical waves can be explained through the development of learning media, one of which is the ripple tank media. This medium is used to investigate the motion of mechanical waves on the water surface (Wahyudi, 2016). This media can be implemented in the classroom through guided inquiry learning. Guided 
inquiry model is a learning model that guides students to find and develop knowledge that is close to life around them through a hypothetical process so as to improve students' conceptual understanding (Doyan et al, 2020). The results of previous studies indicated that the guided inquiry model was more effective at increasing learning outcomes compared to conventional learning (Nurmayani et al, 2018; Susilawati et al, 2019). Applying a laboratory-based guided inquiry model involves students to actively seek and find solutions to the questions given (Rahmat et al, 2019). The inquiry model can also train students' science process skills (Susilawati et al, 2019).

This study aims to develop learning media with a guided inquiry model to improve students' concepts mastery and creativity in physics learning. The learning media in question is a ripple tank to explain the characteristics of a mechanical wave.

\section{Method}

Development research with the $4 \mathrm{D}$ model (define, design, development, dissemination) was conducted in this study (Sugiyono, 2017), where the learning media developed met the criteria of validity, practicality, and effectiveness in improving studen ts' conceptual mastery and creativity. Evaluation of the validity of learning media is carried out through a validation mechanism where the media is validated by 3 validators (media experts) using a validation sheet. Validation is also carried out on learning tools as supporting learning media when implemented in classroom. Evaluation of the practicality and effectiveness of learning media through its implementation in the classroom involving students in two senior high schools in Mataram City - Indonesia. Students in the first school are called students group I and students in the second school are called students group II. The practicality of learning media is measured from the learning feasibility and student responses. Learning feasibility was observed by 2 observers using the observation sheet instrument, while student responses used a questionnaire. The effectiveness of learning media is measured from the improvement in students' concepts mastery and creativity after the implementation of learning media based on the guided inquiry model (analysis of the results of the pretest and posttest). The data on the validity of learning media were analyzed according to Aikens' equation, the practicality of learning media data were analyzed descriptively using the percentage of learning implementation, and the data on the effectiveness of learning media were analyzed using the n-gain equation.

\section{Result and Discussion}

The results of the validation of learning media and supporting learning tools are presented in Table 1. Furthermore, the implementation of learning media in the classroom was carried out and evaluated for its practicality and effectiveness in improving students' concepts mastery and creativity in learning physics. Student responses and learning feasibility are presented in Table 2 and Table 3.

Table 1. The validation results of learning media and learning tools.

\begin{tabular}{lll}
\hline Components & Validation score $(\%)$ & Criteria \\
\hline Learning media & 81,00 & Valid \\
Syllabus & 94,67 & Very valid \\
Lesson plan & 99,26 & Very valid \\
Worksheet & 94,67 & Very valid \\
\hline
\end{tabular}

Table 2. Student responses in learning using developed media.

\begin{tabular}{lll}
\hline Responder & Average $(\%)$ & Criteria \\
\hline Teacher & 92,22 & Very good \\
Student group I & 87,47 & Very good \\
Student group II & 90,47 & Very good \\
\hline
\end{tabular}

Table 3. The results of learning feasibility from two student group.

\begin{tabular}{|c|c|c|c|c|}
\hline \multirow{2}{*}{$\begin{array}{l}\text { Learning } \\
\text { Meeting }\end{array}$} & \multicolumn{2}{|c|}{ Student Group I } & \multicolumn{2}{|c|}{ Student Group II } \\
\hline & Observer & $\begin{array}{l}\text { Observer } \\
\text { II }\end{array}$ & Observer & $\begin{array}{l}\text { Observer } \\
\text { II }\end{array}$ \\
\hline First meeting & 85,71 & 90,48 & 88,52 & 90,48 \\
\hline Second meeting & 90,91 & 90,91 & 90,48 & 90,91 \\
\hline Third meeting & 95,45 & 95,45 & 95,45 & 95,45 \\
\hline Four meeting & 90,91 & 95,45 & 90,91 & 90,91 \\
\hline Fifth meeting & 100,00 & 100,00 & 100,00 & 100,00 \\
\hline Average score & 92,60 & 94,46 & 93,07 & 93,55 \\
\hline Criteria & $\begin{array}{l}\text { Very } \\
\text { good }\end{array}$ & $\begin{array}{l}\text { Very } \\
\text { good }\end{array}$ & $\begin{array}{l}\text { Very } \\
\text { good }\end{array}$ & $\begin{array}{l}\text { Very } \\
\text { good }\end{array}$ \\
\hline
\end{tabular}

The results of the tests on the measurement of students' concept mastery and creativity are presented in graphs in Figure 1 and Figure 2.

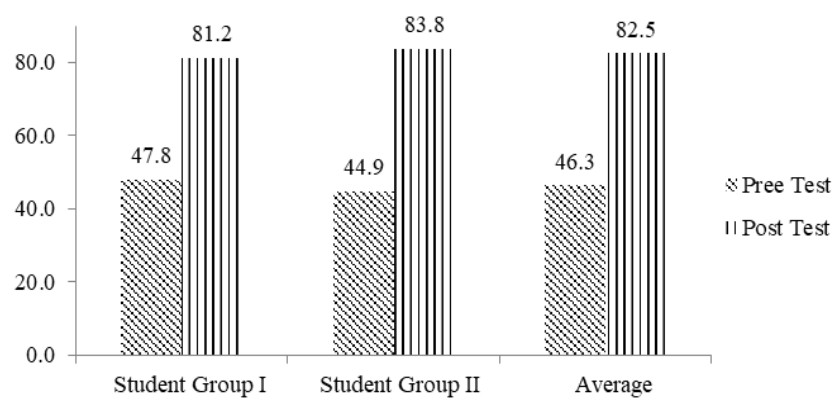

Figure 1. The measurement results of students' concept mastery. 


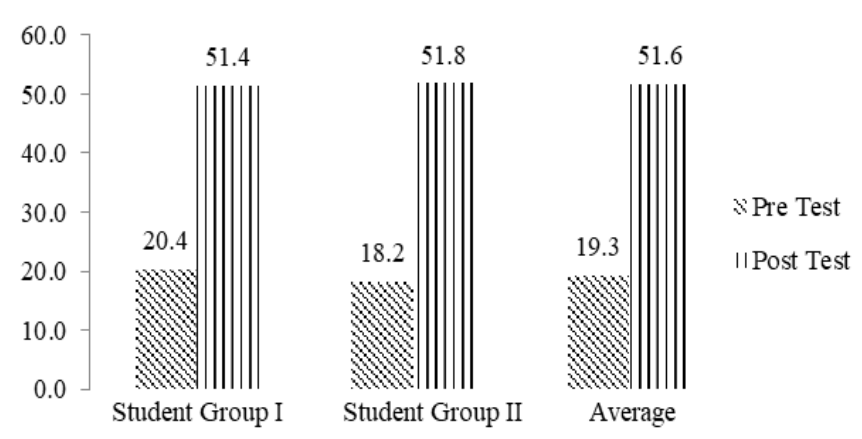

Figure 2. The measurement results of students' creativity

A study on the development of learning media with a guided inquiry model has been carried out to improve students' concepts mastery and creativity in learning physics. The 4D model (define, design, development, disseminate) has been conducted in the development of learning media. The first stage is define, where the initial analysis is carried out by examining the background of the emergence of the researchers' ideas, analyzing tasks and concepts, and formulating specifications for learning objectives and developing learning media. At this stage, the development of learning media with a guided inquiry model has been determined to improve students' mastery of concepts and creativity. The second stage is designing the learning media in the form of a ripple tank to explain the concept of mechanical waves and the preparation of learning tools in the form of a syllabus, lesson plans, and worksheets. The third stage is development, at this stage the validation and implementation of previously designed learning media are carried out. Implementation to evaluate the practicality and effectiveness of learning media in improving students' concepts mastery and creativity. The results of the validation of learning media and supporting learning tools are presented in Table 1.

Through the validation process, the learning media developed has been proven valid and feasible to be implemented in the classroom. Furthermore, the implementation of learning media in the classroom was carried out and evaluated for its practicality and effectiveness in improving students' concepts mastery and creativity in learning physics. Evaluation of measurable practicality of learning feasibility and student responses in learning using the developed media. Learning feasibility and student responses are presented in Table 2 and Table 3.

Learning feasibility of two groups of students from two schools, each by two observers, shows that the learning feasibility with learning media has very good criteria. Likewise with the response from the responders where they responded very well to the learning media developed. These results indicate that the learning media developed have practical criteria in their implementation. Furthermore, the effectiveness of learning media is evaluated, this is measured by the increase in concept mastery and student creativity at the pretest and posttest. The results of the tests on the measurement of students' concept mastery and creativity are presented in graphs in Figure 1 and Figure 2.

Figure 1 shows the average pretest and posttest scores of students' concepts mastery from the two groups of students. The results showed that there was an increase in students' concept mastery scores from pretest to posttest. The $\mathrm{n}$-gain analysis in student group I was 0.64 with moderate criteria, and in student group II it was 0.71 with high criteria.

Figure 2 shows the mean pretest and posttest scores of students' creativity from the two groups of students. The results show that there is an increase in student creativity scores from pretest to posttest. The ngain analysis in student group I and student group II respectively of 0.39 and 0.41 , both of which have moderate criteria. The elaboration of the results in Figure 1 and Figure 2 can be stated that the learning media based on the guided inquiry model is effective in improving students' conceptual mastery and creativity in physics learning. The final stage of this study is the dissemination, at this stage the dissemination of instructional media products, especially to users (physics teachers) in schools, including publishing the results of studies on this media to the public.

In generally, the results of the study show that the learning media based on the guided inquiry model developed are valid, practical, and effective in improving students' concepts mastery and creativity in physics learning. The learning media developed is a ripple tank to explain the characteristics of mechanical waves. The learning media developed in this study are innovative media that have been proven to be able to train students' mastery of concepts and creativity. Innovative media like this is important to continue to be developed by utilizing technology and information, so that students are able to understand the material presented by the teacher well (Doyan et al, 2020). The innovation from the development of this learning media is to take advantage of objects and equipment that are around us and the development of technological science. The developed ripple tank media has several advantages, including being able to visualize the process of forming waves and the interactions that occur between several waves. With this media, it can help students understand the concept of waves better, and increase the creativity of students. 


\section{Conclusion}

The results of the study showed that the learning media with the guided inquiry model were valid, practical, and effective in improving students' concepts mastery and creativity in physics learning. The learning media developed is a ripple tank to explain the characteristics of mechanical waves. The implication is that teachers, especially physics teachers, can apply it in learning to help students in mastering concepts of physics and their creativity.

\section{Acknowledgements}

The researcher would like to thank to the parties involved in this study, including the sponsorship who funded the research process.

\section{References}

Doyan A., Jufri, A. W., Susilawati, Hardiyansyah, A., Auliya, K., Hakim, S., \& Muliyadi, L. (2020) Development of Learning Media of Microscope Po table Auto Design to Inc ease Student's Problem Solving Ability in Light and Optical Tools Topic. Advances in Social Science, Education and Humanities Research, 438,300-303.

Doyan, A., Gunawan, Susilawati, Khasanah, B U. \& Muliyadi, L. (2020). The Effectiveness of Quantum Phenomenon Learning Media with Think Pair Share Model Implementation on Understanding Concept of Students. Journal of Physics: Conference Series, 1521 (2020) 022037,1 -6.

Doyan, A., Susilawati, Kosim, Wardiawan, Z., Hakim, S., Muliyadi, L. \& Hamidi. (2020). The Development of Physics Module Oriented Generative Learning to Increase the Cognitive Learning Outcomes and Science Process Skills of the Students. Journal of Physics: Conference Series 1521 (2020) 022059, 1-6.

Jannah, L. Nur, M., \& Suyono. (2016). Desain bahan ajar materi gelombang dan bunyi model inkuiri terbimbing untuk melatihkan keterampilan proses sains siswa SMP. Pendidikan Sains Pascasarjana Universitas Negeri Surabaya, 6(1).

Kartini, Doyan, A., Kosim, Susilawati, Khasanah, B.U., Hakim, S., \& Muliyadi, L. (2019). Analysis of Validation Development Learning Model Attainment Concept to Improve Critical Thinking Skills and Student Learning Outcomes. Jurnal Penelitian Pendidikan IPA, 5(2), 185-188.

Khasanah, B. U., Doyan, A., Gunawan, Susilawati, Kartini, Hakim, S., \& Muliyadi, L., (2019). Analysis Validation of Learning Media Quantum
Phenomenon. Jurnal Penelitian Pendidikan IPA, 5(2), 189-193.

Lazonder, A. W., \& Harmsen, R. (2016). Meta-analysis of inquiry-based learning. Review of Educational Research, 86(3), 681-718.

Nurmayani, L., \& Doyan, A. (2018). Pengaruh model pembelajaran inkuiri terbimbing terhadap hasil belajar fisika peserta didik. Jurnal Penelitian Pendidikan IPA, 4(2).

Rahmat, I., Chanunan, S., \& Bahri, A. (2019). open inquiry with learning journal promoting metacognitive skills and retention of students with low academic achievements. In $1^{\text {st }}$ International Conference on Advanced Multidisciplinary Research (ICAMR 2018). Atlantis Press.

Sugiyono. (2017). Metode penelitian dan pengembangan (research and development). Yogyakarta: Alfabeta Bandung.

Susilawati, Susilawati, \& Sridana, N. (2015). Pengaruh Model Pembelajaran Inkuiri Terbimbing Terhadap

Keterampilan Proses Sains Siswa. Jurnal Tadris IPA Biologi FITK IAIN Mataram, 8(1), 27-36.

Susilawati, Doyan, A., Harjono, A. \& Kosim. (2019). Penerapan Model Pembelajaran Inkuiri Berbasis Media Virtual Program Java Pada Guru Fisika Dan Siswa SMA. Jurnal Pengabdian Masyarakat Sains Indonesia, 1(1), 4-10.

Susilawati, Doyan, A., \& Ayub, S. (2019). Perbedaan Keterampilan Generik Sains antara Model Pembelajaran Berbasis Masalah dengan Inkuiri Terbimbing Ditinjau dari Kemampuan Berpikir Kritis Siswa SMA. Jurnal Pendidikan Fisika dan Teknologi, 5 (1), 16-24.

Wahyudi, W. (2016). Rancang bangun tangki riak gelombang (ripple tank). Doctoral Dissertation, Universitas Islam Negeri Alauddin Makassar. 